\title{
Teacher-Researcher Development? Unpacking the Understandings and Approaches in Initial Teacher Education in Kosovo
}

FJOLLA KAÇANIKU ${ }^{1}$

$\approx$ The teacher-researcher is a prevailing concept in the post-professionalism age of teacher education. The development of teacher-researchers is discussed alongside reforming initial teacher education programmes as research-based. At this time, there is no consensus regarding the understanding and methodologies of teacher-researcher development. The purpose of this study is to examine student teachers' and teacher educators' understandings of and approaches to teacher-researcher development in initial teacher education in Kosovo within the research-based teacher education movement. The study used a qualitative research design. The data were collected through open questionnaires $(n=270$ student teachers), interviews ( $n=15$ teacher educators), and programme content $(n=5)$ at two initial teacher education institutions in Kosovo. Using Healey and Jenkins's research curriculum categories as a guiding framework, the study identified four clusters of contradictory understandings and approaches relating to teacher educator practice and programme values and goals, fragmenting the context of teacher-researcher development in Kosovo. In order to build consensus in teacher-researcher development, coordinated efforts are recommended to address the current isolated and differing understandings and practices within the broader context of initial teacher education.

Keywords: initial teacher education, programme goals and values, student teacher, teacher educator practice, teacher-researcher development

1 Faculty of Education, University of Prishtina, Kosovo; fjolla.kacaniku@uni-pr.edu. 


\section{Razvoj učitelja raziskovalca? Pojasnitev razumevanj in pristopov v začetnem izobraževanju učiteljev na Kosovu}

FJOLLA KAÇANIKU

$\propto$ Učitelj raziskovalec je prevladujoč koncept $\mathrm{v}$ dobi postprofesionalizma izobraževanja učiteljev. Razvoj učiteljev raziskovalcev je obravnavan skupaj z reformiranjem programov začetnega izobraževanja učiteljev v smeri oprtosti na raziskovanju. Trenutno ni soglasja glede razumevanja in metodologije razvoja učiteljev raziskovalcev. Namen te raziskave je preučiti razumevanja in pristope študentov pedagoških smeri ter izobraževalcev prihodnjih učiteljev glede razvoja učiteljev raziskovalcev med začetnim izobraževanjem učiteljev na Kosovu skladno z gibanjem po izobraževanju učiteljev, ki temelji na raziskavah. Raziskava sledi kvalitativnemu raziskovalnemu načrtu. Podatki so bili zbrani prek odprtih vprašalnikov ( $n=270$ študentov pedagoških smeri), intervjujev ( $n=15$ izobraževalcev prihodnjih učiteljev) in pregledov programov $(n=5)$ dveh kosovskih institucij začetnega izobraževanja učiteljev. Uporabljajoč kategorije raziskovalnega predmetnika Healeyja in Jenkinsa kot vodilni okvir, je raziskava odkrila štiri skupke nasprotujočih si razumevanj in pristopov, povezanih s prakso izobraževalcev prihodnjih učiteljev ter programskimi vrednotami in cilji, kar lomi kontekst razvoja učitelja raziskovalca na Kosovu. Da bi dosegli soglasje glede razvoja učitelja raziskovalca, so potrebna usklajena prizadevanja, ki bi v širšem okviru naslovila trenutno izolirana in različna razumevanja ter prakse začetnega izobraževanja učiteljev.

Ključne besede: začetno izobraževanje učiteljev, programske vrednote in cilji, študent pedagoških smeri, praksa izobraževalca prihodnjih učiteljev, razvoj učitelja raziskovalca 


\section{Introduction}

Reforming initial teacher education has been actively debated for many years (Darling-Hammond \& Bransford, 2005; Darling-Hammond, 2016, 2017; Hargreaves, 2003). The teaching profession is becoming increasingly complex due to the expansion of its scope of work in the age of the knowledge society (Darling-Hammond, 2017). Hargreaves describes teachers as catalysts of the knowledge society and emphasises the fact that teachers must establish a culture of professionalism comprising creativity, problem-solving, research-orientation, flexibility in coping with change, and continuous professional development (Hargreaves, 2003). Initial teacher education institutions therefore play a decisive role in reforming programmes to prepare future teachers for this wider range of tasks and expectations (Darling-Hammond, 2016, 2017).

According to Niemi (2008), European policy initiatives in teacher education aim to improve the competencies of future teachers by promoting a research orientation. In this context, Niemi (2008) refers to the European Commission's assertion, "teacher education should be based on research and teachers' work requires abilities to reflect the evidence on which they base their practice" (p. 203). Moreover, current high-quality initial teacher education programmes prioritise research and development, reflective practice and the development of teacher-researchers (Buchberger, Campos, Kallos, \& Stephenson, 2000).

In the growing literature on research-based initial teacher education, Finland is considered a pioneer (Afdal \& Spernes, 2018; Alvunger \& Wahlström, 2018; Krokfors et al., 2011; Munthe, \& Rogne, 2015; Niemi, 2008; Puustinen, Säntti, Koski, \& Tammi, 2018). However, (1) there is still no common understanding of what constitutes preservice teacher-researcher development. In addition, (2) studies show that a context-based approach is important to understanding the design and delivery of research-based activities in developing teacher-researchers (Afdal \& Spernes, 2018). Furthermore, (3) the discussion of research-based teacher education focuses on Western European countries, while research-based initial teacher education in Eastern Europe and the Western Balkans remains under-researched.

The present study focuses on a small and "peripheral" European context. Initial teacher education in Kosovo transferred to universities in 2002. Previously, teacher education had been organised in higher pedagogical schools (HPS - teacher training institutions) located in major cities throughout Kosovo. When the transfer took place, these training institutions initially operated as branches of the University of Prishtina (beginning in 2002), and the Faculty of Education 
in Prishtina was thus the largest teacher education institution in the country. By 2010, however, the branches had evolved into independent initial teacher education institutions. Today, Kosovo's five initial teacher education institutions are Faculties of Education operating under the banners of five public universities in Kosovo (Saqipi, 2019).

Since Kosovo is aiming to join European structures, discussions about teacher quality and raising teacher professionalism have become more relevant, triggering major reforms within teacher education (Kaçaniku, Gjelaj, \& Saqipi, 2019; Saqipi, 2019, 2020). Programme reforms have followed Bologna Process objectives in order to ensure compatibility and comparability of degree structures by introducing ECTS and the three-cycle system as well as undergoing programme accreditation as a quality assurance mechanism (Kaçaniku, 2017, 2020). Specific initiatives have aimed to improve the quality of teacher education programmes. In 2010, the Faculty of Education of the University of Prishtina developed the first two master-level programmes, which promoted the use of research to improve practice in developing education practitioners. In 2014, supported by an EU-funded project, the Faculty of Education established 12 new master-level programmes to develop the professionalism of subject teachers. In the same year, the EU granted the institution a capacity-building project award to modernise teacher education (Saqipi, 2019).

The aim of these projects was to advance student teachers' reflection and research skills (Kaçaniku et al., 2019; Saqipi \& Vogrinc, 2016). All of the programmes integrated at least one research methods course (Saqipi, 2020). In addition, both BA and MA programmes require student thesis work (Saqipi \& Vogrinc, 2016).

The present study examines student teachers' and teacher educators' understandings of and approaches to teacher-researcher development in initial teacher education (ITE) within the research-based teacher education movement. Employing qualitative methods research design, ITE in Kosovo was examined using programme documents, teacher educators' perceptions and student teachers' perceptions. The study addressed the following research questions:

(1) How is the meaning and purpose of the teacher-researcher concept understood within initial teacher education?

(2) How does initial teacher education approach the development of teacher-researchers?

(3) What kinds of factors can explain conflicting understandings and approaches in teacher-researcher development? 


\section{Theoretical framework}

The context of developing teacher-researchers is best achieved by implementing research-based teacher education. In research-based ITE, programmes are designed such that all modules integrate research (Jyrhämä et al., 2008) and teacher-researchers are educated in research concepts from the first day of the programme (Toom et al., 2010). Scholars contend that research-based programmes have two important features: 1) they include modules with integrated research, and 2) teacher educators constantly conduct research and engage their students in the processes of research (Afdal \& Spernes, 2018; Alvunger \& Wahlström, 2018; Jyrhämä et al., 2008; Krokfors et al., 2011; Munthe \& Rogne, 2015; Niemi, 2008).

In research-based programmes, the development of teacher-research competences is a complex process (Krokfors et al., 2011). According to Niemi and Nevgi (2014), future teachers need: 1) critical research literacy and 2) research for profession. Critical research literacy demands that future teachers develop a readiness for inquiry, analyse research literature, question foundational education knowledge, become critical thinkers, develop methods for knowledge creation, and apply this knowledge to their practice. Research for profession refers to future teachers' understanding of the importance of the teaching profession in society, their understanding of teaching as a continuous professional development process, their internalisation of the importance of research for improving practice, and their understanding of the expanded roles and responsibilities of teachers, as well as the research-based development of the school and the development of educational responsibility (Niemi \& Nevgi, 2014, p. 137). Thus, research-based ITE should go beyond developing technical research skills and focus on developing positive attitudes towards becoming teacher-researchers (Afdal \& Spernes, 2018; Alvunger \& Wahlström, 2018; Krokfors et al., 2011; Niemi \& Nevgi, 2014).

Research-based programmes provide future teachers with opportunities to engage in research activities. These activities provide them with a platform to both study and analyse the thinking of their students (Afdal \& Spernes, 2018). Future teachers can develop self-evaluation skills allowing them to examine and engage in decision-making and problem-solving around their practice (Niemi \& Nevgi, 2014; Puustinen et al., 2018). Moreover, prospective teachers grow to understand the importance of evidence-informed practice and the establishment of collegiality platforms, as well as the necessity of advancing a culture of assessment that fosters context-driven improvements (Niemi, 2008). Finally, they develop positive attitudes towards studying and conducting research in their future work (Munthe \& Rogne, 2015). 
ITE research exercises and activities prepare future teachers to teach based on evidence and reflection (Alvunger \& Wahlström, 2018; Jyrhämä et al., 2008). They do not require student teachers to become scientific researchers who design novel studies that generate scientific results. Instead, the intention of research-based study programmes is to develop a "practitioner-researcher orientation" in future teachers, providing them with a lifelong framework for improving their practice. Ultimately, the goal of a research-based orientation is to prepare teacher-researchers for a wide range of scenarios and stakeholders in their future work by ensuring they possess a variety of competencies and a range of knowledge (Alvunger \& Wahlström, 2018; Puustinen et al., 2018).

In order to build a conception of what a developing teacher-researcher actually is within an ITE programme, Stenhouse (1981) posed the question: What counts as research? He argued that research is a "systematic process" and "conscientiously self-critical inquiry" (p. 109), and he placed great emphasis on research interest, relating it to research curiosity and arguing that "inquiry is founded in curiosity and a desire to understand; but it is a stable, not a fleeting, curiosity, systematic in the sense of being sustained by a strategy" (p. 103).

A great deal of evidence shows that research-based ITE can have different meanings and approaches in different contexts. Studies show that academic staff of different disciplines reflect diverse perspectives on how to approach research work (Griffiths, 2004; Healey, 2005; Krokfors et al., 2011). The present study employs a framework devised by Healy and Jenkins (2009) in order to capture different perceptions of research-based ITE and teacher-researcher development. This framework presents different conceptualisations of researchdriven curriculum design (see Figure 1). 


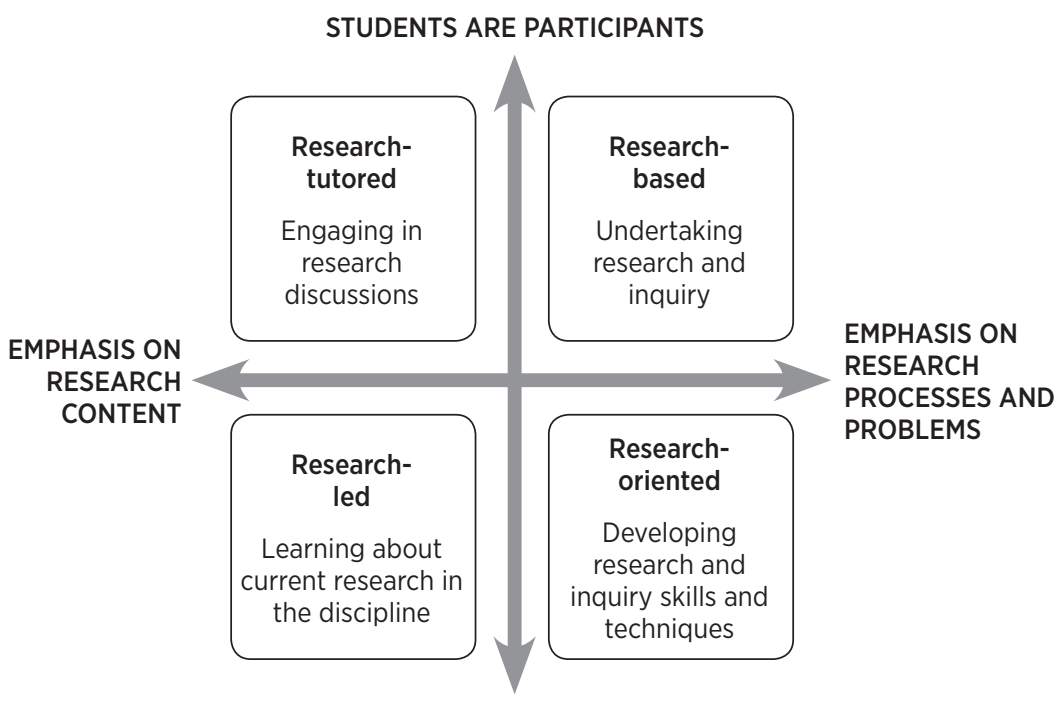

\section{STUDENTS ARE AN AUDIENCE}

Figure 1. The nature of research-oriented programmes. Adapted from Healey \& Jenkins, 2009, p. 7.

In this framework, the design and delivery of a research-driven programme follow four different approaches: (1) the research-led approach exposes students to existing education research, (2) the research-oriented approach develops students' research methods and techniques, (3) the research-tutored approach engages students in reflections and research discussions, and (4) the research-based approach encourages students to undertake research (Healey \& Jenkins, 2009). In the present study, this framework provides a valuable basis for examining the different groups' perceptions of their understanding of and approaches to teacher-researcher development in ITE in Kosovo.

\section{Method}

\section{Sampling, instruments and procedure}

The study used a qualitative method approach (Creswell, 2014) and was conducted in two public initial teacher education institutions in Kosovo during the 2017/2018 and 2018/2019 academic years. The selected institutions represent one larger and one smaller institution (see Table 1 for more information). 
Table 1

Sample characteristics of study subjects

\begin{tabular}{lcc}
\hline $\begin{array}{l}\text { Programmes } \\
(n=5)\end{array}$ & $\begin{array}{c}\text { Student teachers } \\
(n=270)\end{array}$ & $\begin{array}{c}\text { Teacher educators } \\
(n=15)\end{array}$ \\
\hline Institution A & 126 & $9 \mathrm{a}$ \\
Elementary Teacher Education (BA) & 12 & 4 \\
Pedagogy for Vocational Education (MA) & 10 & 4 \\
Teaching and Curriculum (MA) & 32 & 9 \\
Subject Teacher Education (MA) & & 3 \\
\hline Institution B & 90 & \\
Elementary Teacher Education (BA) & & \\
\hline
\end{tabular}

Note. $\mathrm{a}=$ This column shows the distribution of sampled teacher educators in all of the selected programmes out of the total number of sampled teacher educators.

\section{Programme documents}

The study programmes $(n=5)$ were chosen with a purposive sampling strategy (Creswell, 2014). Maximum variation sampling was used to identify programmes that represent different levels (BA and MA) and focuses (pedagogy-oriented and subject didactics-oriented) of teacher education. Programme documents were selected a) to identify the number of courses related to research, b) to explore how research is integrated into different courses and programmes, and c) to investigate course descriptions/requirements of students' learning outcomes that included a research element or explicitly planned teacher-researcher development.

\section{Open questionnaire}

The student teachers $(n=270)$ voluntarily responded to an open questionnaire (Creswell, 2014). The questionnaire was shared with all of the student teachers $(n=410)$ in the selected programmes, and $65.85 \%(n=270)$ of them participated. Questionnaires with open-ended questions are more in-depth and reveal the unique perspectives of respondents (Creswell, 2014). The questionnaire consisted of five background questions and six open-ended questions covering the following themes: (i) education research, (ii) the notion of teacherresearchers and its relevance to the teaching profession, (iii) research-based teacher education and research integration within programmes, (iv) appreciation of research activities and practical research engagement, (v) development as 
teacher-researchers, and (vi) future research engagement prospects and benefits to the teaching practice. All of the students were instructed to respond in depth to each question, i.e., with at least 150 words per question.

\section{Semi-structured interviews}

The teacher educators $(\mathrm{N}=15)$ were selected with a purposive sampling strategy (Creswell, 2014). Maximum variation sampling was used to identify a variety of teacher educators based on the criteria of selected programmes, gender, disciplines, research and lecturing experience and academic rank, thus covering the entire spectrum of perceptions. The total number of teacher educators matching each criteria was very low (1-2), and the small number of teacher educators in ITE made the selection process straightforward. The interview protocol included seven background questions and ten open-ended questions with the same themes as the student teacher open questionnaire (with additional prompts and sub-questions). The responses were used to examine the perspectives of teacher educator understandings and approaches regarding teacher-researcher development.

\section{Data analysis}

The study used thematic analysis to analyse the different understandings of and approaches to teacher-researcher development in ITE in Kosovo, underlining similarities and differences, and generating unanticipated understandings (Braun \& Clarke, 2006). According to Creswell (2014), using thematic analysis powers researchers to generate important study characteristics. In this case, it covered heterogeneous data: i) programme documents, ii) an open student teacher questionnaire, and iii) teacher educator interviews. As Nowell et al. (2017) recommend, research questions guide the thematic analysis. Braun and Clarke's (2006) six-phased method was selected for thematic analysis:

(1) Familiarisation with data: The interview data were transcribed verbatim in the Albanian language (approximately 7 pages per interviewee, totalling 105 pages of transcribed text). Some selected interview excerpts were translated into English. The open questionnaires totalled 1,350 pages (approximately 5 pages per student teacher) and the programme documents totalled 97 pages (ranging from 18 to 25 pages per programme). Data triangulation ensured credibility of analysis (Lincoln \& Guba, 1985). All of the text data were arranged and converted into raw data for smooth transfer to ATLAS.ti qualitative software for data sorting and 
organising. All of the text data was read and re-read for initial insights and familiarisation with the text.

(2) Generating initial codes: Healey and Jenkins's (2009) framework was used to analyse all of the text data. Supported by this framework, a code manual was developed to provide comprehensive definitions and example texts for each curriculum category. This coding framework ensured an organised approach to combining three sets of data into a common analysis identifying and examining different teacher-research understandings and approaches from data text. According to Nowell et al. (2017), a coding framework is useful for novice researchers because it ensures transparent and credible analysis. ATLAS.ti qualitative software ensured an organisation of coding consistent with the interesting features throughout the text, thus enabling depth and sophistication of thematic analysis.

(3) Searching for themes: The identified codes from the previous stage were organised into possible themes, corresponding to the curriculum categories in the Healey and Jenkins (2009) framework.

(4) Reviewing themes: In this stage, all of the themes and codes were reviewed to develop an analysis map and ensure that all of the generated analysis was logically connected. Although personal reflection was present in all stages of data analysis, captured as reflective journal entries, this stage also involved debriefing with the research mentor in order to vet the emerging themes. This type of external consultation ensured credibility and valid interpretation of the analysed text (Lincoln \& Guba, 1985).

(5) Defining and naming themes: The previously generated themes were refined. A detailed analysis for each theme ensured that the individual themes convey a transparent and complete picture in relation to the research questions and guaranteed transferability of the findings (Lincoln \& Guba, 1985).

(6) Producing the report: The final themes were verified at this stage. The findings were organised according to research questions and Healey and Jenkins's (2009) framework. Block and shorter quotations delineate the respondents' perceptions and direct text from the programme analysis. Each sub-section of the findings is intended to synthesise outcomes from all of the data sources. The themes and detailed descriptions are presented in Table 2. 


\section{Results}

The data were analysed in relation to the research questions. The first section of the results responds to the first and the second research questions, which involve the understanding of and approaches to teacher-researcher development within initial teacher education. The findings in this section are synthesised based on Healey and Jenkins's (2009) curriculum categories. The second section answers the third research question, showing factors explaining conflicting understandings and approaches in teacher-researcher development emerging from the context of ITE. Both results sections show the reality of teacher-researcher development within ITE in Kosovo.

\section{Understandings of and approaches to teacher-researcher development within initial teacher education}

Based on the four curriculum categories of Healey and Jenkins (2009), the thematic analysis shows several themes emerging as four ways in which teacher-research development is understood and approached within ITE. Themes and detailed findings are organised in Table 2 and represent the perceptions of teacher educators and students teachers, as well as programme content analysis.

Table 2

Understanding and approaching teacher-researcher development in ITE in Kosovo

\begin{tabular}{|c|c|c|}
\hline $\begin{array}{l}\text { Curriculum } \\
\text { categories }\end{array}$ & Themes & Detailed findings \\
\hline $\begin{array}{l}\text { Research- } \\
\text { led }\end{array}$ & $\begin{array}{l}\text { Formal learning } \\
\text { about education } \\
\text { research }\end{array}$ & $\begin{array}{l}\text { - Focus devoted to subject and pedagogical content knowledge } \\
\text { - Theoretical knowledge for teaching } \\
\text { - Memorise the main notions and concepts } \\
\text { - Teacher-centred frontal lecturing style } \\
\text { - Transmission of knowledge is the main teaching approach } \\
\text { - Lack of student engagement } \\
\text { - Summative assessment approach } \\
\text { - Exams assess content knowledge }\end{array}$ \\
\hline \multirow[t]{2}{*}{$\begin{array}{l}\text { Knowledge } \\
\text { of education } \\
\text { research }\end{array}$} & $\begin{array}{l}\text { Research and } \\
\text { teaching as two } \\
\text { separate teacher } \\
\text { activities }\end{array}$ & $\begin{array}{l}\text { - Teaching relevant knowledge } \\
\text { - Teaching is not research } \\
\text { - Research as a complex task that is not dedicated to teachers } \\
\text { - Research is only seen in terms of new knowledge production }\end{array}$ \\
\hline & $\begin{array}{l}\text { Limited research } \\
\text { infrastructure }\end{array}$ & $\begin{array}{l}\text { - Limited access to online databases } \\
\text { - Physical library and lecture notes } \\
\text { - Promote the use of outdated native literature } \\
\text { - English language as a barrier }\end{array}$ \\
\hline
\end{tabular}




\begin{tabular}{|c|c|c|}
\hline $\begin{array}{l}\text { Curriculum } \\
\text { categories }\end{array}$ & Themes & Detailed findings \\
\hline \multirow{2}{*}{$\begin{array}{l}\text { Research- } \\
\text { oriented } \\
\text { Research } \\
\text { Skills }\end{array}$} & $\begin{array}{l}\text { A narrow view } \\
\text { of research skills } \\
\text { development }\end{array}$ & $\begin{array}{l}\text { - Only one research methods course per programme } \\
\text { - Isolated view of developing research skills } \\
\text { - Emphasises research methods knowledge } \\
\text { - Transmission of knowledge of research techniques is abstract } \\
\text { - Students are full-time receivers } \\
\text { - Limited research-oriented activities and assignments } \\
\text { - No practical research engagement } \\
\text { - Research knowledge assessed through exams }\end{array}$ \\
\hline & $\begin{array}{l}\text { Thesis work as } \\
\text { the only research } \\
\text { engagement }\end{array}$ & $\begin{array}{l}\text { - Student teacher thesis work required } \\
\text { - Thesis work starts at the end of the programme } \\
\text { - Student teachers submit project proposal at the department level } \\
\text { - Reviewing thesis proposals and thesis mentoring poorly managed } \\
\text { - Students have limited skills to properly complete thesis work } \\
\text { - Thesis work perceived as a formality }\end{array}$ \\
\hline $\begin{array}{l}\text { Research- } \\
\text { tutored } \\
\text { Reflection } \\
\text { on education } \\
\text { research }\end{array}$ & $\begin{array}{l}\text { Analytical and } \\
\text { reflective skills } \\
\text { and attitudes } \\
\text { to education } \\
\text { problems }\end{array}$ & $\begin{array}{l}\text { - Develop skills to access new knowledge of education problems } \\
\text { - Critical and analytical skills by reviewing the literature } \\
\text { - Guided discussion using probing } \\
\text { - Student teachers receive feedback from teacher educators and peers } \\
\text { - Student-centred discussions to bridge theory and practice } \\
\text { - Encourage group work and collegiality } \\
\text { - Critical conversations in rebuttals between two or more groups } \\
\text { - Students are contributors to course development } \\
\text { - Mixed assessment strategies focusing on formative assessment }\end{array}$ \\
\hline $\begin{array}{l}\text { Research- } \\
\text { based } \\
\text { Research } \\
\text { action }\end{array}$ & $\begin{array}{l}\text { Missing research- } \\
\text { based teacher } \\
\text { education }\end{array}$ & $\begin{array}{l}\text { - Research is not limited to research methods courses } \\
\text { - All courses can develop research skills } \\
\text { - Research skills are not limited to technical research skills } \\
\text { - There are many ways of exposing student teachers to research } \\
\text { - Student-centred teaching and learning } \\
\text { - Reading and analysing education research } \\
\text { - Practical research activities } \\
\text { - Group research projects in schools } \\
\text { - Discussion and presentation of findings } \\
\text { - Research as reflection } \\
\text { - Guidance and feedback } \\
\text { - Students are contributors to course development } \\
\text { - Mixed assessment strategies }\end{array}$ \\
\hline
\end{tabular}

\section{Research-led understandings and approaches}

The results demonstrate that in Kosovo ITE, the following themes describe research-led TE: formal learning about education research, research and teaching as two separate activities and limited research infrastructure.

\section{Formal learning about education research}

Findings show that teacher educators view and approach teacher-researcher development using a knowledge-based strategy. The data clearly shows that teacher educators primarily use a teacher-centred lecturing style that lacks student engagement to convey and discuss the knowledge of research in the teaching profession. Consequently, the approach to developing 
teacher-researchers, as reported by many teacher educators, is restricted to formal learning about education research.

Professors have an academic background that shifts the focus of programmes to academic [theoretical] oriented teaching and learning. [...] The typical teacher educator approach is frontal lecturing and a knowledge-based orientation. (Teacher Educator 2)

The courses teacher educators teach focus on student teachers' strong knowledge of teaching and learning and subject matter. The following quotes from the programme analysis show that learning about the teaching profession has a knowledge focus.

Gaining knowledge and learning the rules of the teaching and learning of different learning areas, as well as becoming acquainted with the relationships between learning processes, on the one hand, and the individual and society, on the other. (Programme 1, p. 90)

Deepening and expanding knowledge in the field of linguistics in general and the organisation of the text (syntax) in particular. (Programme 4, p. 114)

Moreover, the results infer that the teacher educators' formal approach to education research has led to mechanical learning among student teachers.

Students are pushed to learn through memorising and mastering content knowledge. (Teacher Educator 3)

The teacher educators' assessment of the students' knowledge of education research is limited to exams, while group work and practical engagement strategies are ignored.

Most courses in our programme use theoretical lecturing that lacks practical engagement. (Student Teacher 27)

This means that students' exposure to teaching profession research is approached in isolated knowledge-based learning. This cluster was mostly comprised of subject discipline teacher educators. 


\section{Research and teaching as two separate teacher activities}

The findings show that some teacher educators and courses approach research and teaching as two separate teacher activities within the teaching profession. When discussing teacher-researcher development, teacher educators questioned the importance of teachers engaging in research.

I do not see how future teachers will use research in their work. They are teachers responsible for teaching, not researchers. (Teacher Educator 8)

Research is a complex task and teachers need extensive scientific research skills to be able to conduct research and produce new knowledge. I simply do not see how teachers can be researchers, nor do I see the purpose of them becoming researchers. (Teacher Educator 14)

The teacher educators and student teachers discussed how developing the teacher-researcher has not been a priority in study programmes.

Research integration is at a minimal level and can be considered the least prioritised aspect of our programmes. Teaching and knowledge transmission remain the main activities in teacher educator practice. (Teacher Educator 7)

The study respondents established knowledge of the teaching profession as the guiding theme in ITE. The respondents noted the complete absence of research in their programme of study.

During our studies, teacher-research was never mentioned as a responsibility. I do not see how research will be incorporated in our future work realities on top of other demands of the teaching profession. (Student Teacher 12)

Our programme does not support research work and its entire approach is dedicated to teaching methods and learning. There were no research-oriented assignments, either (Student Teacher 33)

These statements reveal that some teacher educators do not integrate teacher-researcher development into their teaching because they consider research irrelevant to teaching. This means that teacher-researcher development is missing in courses. The teacher educators' beliefs that the work of a teacherresearcher is limited scientific research clearly influences how student teachers understand and approach research in their future work. As a consequence, the 
student teachers had already detached themselves from the possibility of future research engagement before starting their careers.

\section{Limited research infrastructure}

The theme of limited research infrastructure details various barriers to accessing and exploring education research.

Although our institution subscribes to online research databases, limited or no access is granted to students. The majority of students have a limited command of the English language, which makes it impossible for staff to recommend updated articles in a foreign language to students. (Teacher Educator 9)

In the absence of literature, teacher educators prepare lecture notes as the only literature for an entire course. These teacher educators will test students based on the prepared lecture notes and this is extremely detrimental to the students' research spirit. (Teacher Educator 1)

\section{Research-oriented understandings and approaches}

The results show that a research-oriented curriculum is approached under the following themes: a narrow view of research skills development and thesis work as the only research engagement.

\section{A narrow view of research skills development}

The results show how teacher-researcher development is viewed as limited to technical research skill development, while research skill development is limited to one course in the programme: a research methods course. The teaching of research skills is not integrated into any other courses, thus leading student teachers to develop and experience research as a component of education that is separate from their teaching practice during their ITE.

All of our programmes have at least one research methods course. However, the purpose of methods courses is to emphasise more formal aspects of research techniques, which is supposed to help students with thesis preparation at the end of the programme. (Teacher Educator 2)

In the research methods course, teacher educators deliver abstract, teacher-centred lectures lacking concrete materials. Student teachers' technical research knowledge is assessed through formal exams and limited student 
assignments. Research proposal assignments require no practical research.

I do not expect to develop research skills by only attending one research techniques course, nor do I expect to know how to approach research in my future work as a teacher. [...] Scientific research is too demanding for me as a future teacher. (Student Teacher 121)

The results indicate that both teacher educators and course implementations have narrowed research orientation to technical research skills and established knowledge of research methods in theory. No process of a mindset change for teacher-researcher development was reported.

\section{Thesis work as the only research engagement}

The results show that teacher-researcher development is approached during the thesis project at the end of the programme. However, the study respondents share the view that while thesis work is considered a rich research experience for student teachers in theory, in reality the process is only a formality for fulfilling programme requirements.

The thesis project is not approached as a small-scale project that is supposed to help student teachers understand how research helps to improve classroom practice; instead, it is usually broad and theoretical, and does not consider its social application. (Teacher Educator 7)

Although students are required to submit a research proposal at department level, due to the high teacher-student ratio, the process of evaluating and mentoring the student thesis is not properly managed. From my experience as a department head and a teacher educator, I can tell you that we do not have the capacities to provide detailed feedback to student proposals, especially for a BA thesis. We have therefore sometimes allowed students to graduate with substantial thesis problems, thus turning this process into a formality. (Teacher Educator 15)

Student teachers shared the view that courses have not provided skills development consistently throughout the programme. Therefore, they do not feel skilled enough to engage in research tasks.

Our programme did not expose us to research activities and assignments at all. We are now almost at the end of the programme and we will soon be faced with 
thesis work requirements. However, I can say that we are 'zero' prepared for undertaking such a challenging task. One course at the end of the programme is not adequate. (Student Teacher 2)

This discussion clearly indicates that thesis work is approached as a formality and does not yield productive student research engagement. Consequently, a distorted perception of the thesis has developed: it is viewed as a mandatory research activity for programme completion instead of a valuable experience for the teaching profession.

\section{Research-tutored understandings and approaches}

The thematic analysis did, however, reveal some signs of implementing a research-tutored approach in ITE in Kosovo with the following theme: analytical and reflective skills and attitudes to education problems.

Analytical and reflective skills and attitudes to education problems

Supporters of research-tutored understandings and approaches encourage teacher-researcher development by facilitating classroom discussions of education problems to bridge theory and practice. Students receive guidance and feedback to foster critical conversations and encourage group work. This approach facilitates growth of student teachers' reflective skills, rather than technical research knowledge.

Reflective discussions allow student teachers to exchange ideas, judge education problems critically and make joint decisions. (Teacher Educator 13)

Student reflective discussions are evaluated using guidance and feedback to influence an analytical and reflective student attitude to education problems. (Teacher educator 5)

Reflective discussions are assessed using multiple strategies. Reading and analysing international literature challenges student teachers and strengthens their English language skills. These assignments are particularly valuable as student teachers often do not yet have strong English language skills. Student teachers contribute to course development. Their assignments reflect reviewing and assessing texts, organising ideas, generating critical analysis, and discussions. In addition, students develop a strong sense of collaborative work. This approach is embraced by teacher educators in the field of pedagogy, who 
promote a more open view to defining and approaching teacher-researcher development.

\section{Research-based understandings and approaches}

The findings show missing research-based teacher education, which is discussed under this theme.

\section{Missing research-based teacher education}

The findings reveal that only a few teacher educators in the study view and approach teacher-researcher development holistically.

There is a need to develop the teacher-researcher through a holistic approach that goes beyond technical research methods courses. This allows future teachers to free themselves from the knowledge gained in the research methods course and ensures that they develop a wide range of research skills throughout various courses in their programme, [...] including analysis, critical thinking, reflection, and action research. In other words, teacher-researcher development is an inclusive process (Teacher Educator 7)

This approach promotes teaching and learning by guiding student research and reflective work. Education research is understood and approached through context and situation-dependent methodologies that enable problemsolving. Student teacher assignments are demanding, and as a result student teachers produce high-quality work.

With the help of my teacher educator, I planned and engaged in action research to inform and improve my teaching practice. (Student Teacher 205)

This small but significant group of teacher educators strives to develop a culture of teacher learning as a lifelong process by developing teacher-researchers. This approach empowers student teachers to understand any form of research activity - from reviewing education research and reflection, to action research - as teacher-researcher approaches that improve the quality of their future practice. This cluster was comprised mostly of teacher educators in the field of pedagogy, as well as a few subject teacher educators. 


\section{Factors explaining conflicting understandings and approaches in teacher-researcher development}

The results show that factors explaining conflicting understandings and approaches in teacher-researcher development relate to: (a) teacher educator discipline and (b) programme goals and values. Both themes represent context-based elements and show how they are manifested in the course of teacher-researcher development. The influence of teacher educator discipline and programme goals and values in teacher-researcher development are discussed simultaneously, as examining aspects related to programmes while isolating the influence of teacher educator practice is almost impossible.

When discussing programme goals and values, there is a consensus among teacher educators that implementing programme regulations is coursespecific and depends on the teacher educator's approach. The findings of the present study show that understanding the teacher-researcher concept, integrating it within course design and delivery, and approaching teacher-researcher development is often strongly aligned to the teacher educator's own discipline. Consequently, when discussing teacher educator practice, the interviewees described a clear divide between perceptions of teacher educators of pedagogy and of subject disciplines in the context of teacher-researcher development. The results show that the majority of subject teacher educators regard one research methods course for developing teacher-researchers as "enough". There is a consensus among subject teacher educators that teacher-research development is fully supported by knowledge of scientific research.

As a subject academic staff member, I teach students research methods using knowledge of scientific research methods. Knowledge of the research process is the most powerful weapon for future teachers' research engagement. Thus, teachers should have a strong knowledge of scientific research methods to engage in research and produce new findings. (Teacher Educator 2)

At the same time, other teacher educators, mostly in the field of pedagogy, believe that various approaches should be employed to integrate research into different courses for teacher-researcher development.

The teacher-researcher cannot be developed through one methods course; research should be integrated into all courses, regardless of the nature of the course, through different activities that teacher educators design and deem appropriate. Such an approach focuses on the teacher-researcher's analytical, 
critical and reflective skills, and is oriented towards problem-solving. (Teacher Educator 3)

The teacher-researcher is someone who tries different approaches and then tests the ones that fit better within the school and classroom context. They value collegial work to address education problems. It is important to emphasise that action research is not their only research activity; the teacher-researcher engages in a wide range of inquiry-based activities to improve teaching practice. Teachers are practice-based, not scientific researchers. Hence, research activities are inclusive and not limited. (Teacher Educator 1)

The teacher educators' statements show tensions between teacher educators of different disciplines, reflecting diverse values and attitudes regarding their understanding of and approach to teacher-researcher development. Teacher educator flexibility and individuality in course implementation were distinguished as important contextual elements derived from the data. The development of teacher-researchers therefore emerges as ad hoc and isolated, and does not follow any solid programmatic approach.

The main course that integrates research is research methods. Other courses focus more on knowledge. Courses that integrate research aspects the least are academic subjects. In short, the level of research integration in my programme depends on teacher educators and courses. (Student Teacher 261)

The data also revealed that subject teacher educators teach research methods in subject teaching programmes, while pedagogy teacher educators do so in more general education programmes. This approach of assigning methods courses based on the teacher educator's discipline has monopolised the understanding of and approach to education research and teacher-researcher development based on disciplinary frames.

\section{Discussion and Conclusion}

The purpose of this study was to examine the understandings of and approaches to teacher-researcher development in initial teacher education in Kosovo. The research found that the understanding of a research-based orientation and how it is approached within initial teacher education relates to the teacher educator's practice and the programme's values and goals. The study revealed important context-related tensions and how they manifest in 
teacher-researcher development. Contextual relevance in teacher-researcher development is discussed in terms of four clustered understandings and approaches under Healey and Jenkins's (2009) framework.

First, the results show that limited and formal learning about education research through knowledge transmission emerged as the main teacher development approach. Teachers do not develop into researchers due to an understanding of research in terms of "scientific research" task complexity. While various studies (see: Alvunger \& Wahlström, 2018; Jyrhämä et al., 2008) emphasise the fact that teacher-researcher development does not mean teachers becoming scientific researchers who generate novel results, the results of the present study indicate that many teacher educators and courses continue to strongly support a disciplinary and knowledge-based understanding of teacher-researcher development. The practical implication of our results is that prospective teachers do not link research with teaching practice.

Second, the results reveal that content knowledge of research techniques and thesis work are the main components of teacher-researcher development. Our results partly align with Krokfors et al. (2011) in considering the organisation of research-based orientation through the BA and MA student thesis as natural. However, our findings show that research skills development is approached in isolation, limited to a research methods course. Consequently, our results differ from Toom et al. (2010) in suggesting that teacher-researcher development is a multifaceted process organised throughout the programme. The consequence of our findings in practice indicates that teacher-researcher development is equivalent to teacher technical research skills.

Third, the results support the idea that student teachers develop reflective skills and attitudes towards education problems concerning their future practice. Our finding corresponds to that of Afdal and Spernes (2018) in arguing for the research nature of reflective practice. The interpretation of our results infers that in a limited segment, Kosovo ITE has broadened teacher-researcher development in terms of teacher reflective practice.

Fourth, the results demonstrate that teacher-researchers develop though different research-oriented activities in various courses within programmes. Our results indicate that teacher-researcher development necessitates a multifaceted and continuous approach. Similar to other studies (see: Afdal \& Spernes, 2018; Alvunger \& Wahlström, 2018; Jyrhämä et al., 2008; Krokfors et al., 2011), our findings support the view of teacher-researcher development as not limited to developing student teacher research skills, but including a wide range of teacher-research roles and attitudes, such as critical thinking and reflection, continuous teacher growth and research engagement for classroom and school 
improvement, among others. As suggested by Niemi and Nevgi (2014), being a teacher-researcher requires a much broader skillset than technical research skills alone.

However, the major results in the Kosovo context show that technical research skills development remains the only segment of the "larger pie" of teacher-researcher development. This narrow approach stems from a history of isolating research in one methods course, emphasising research content knowledge transmission in which students act as an audience, the development of theoretical research skills, and the perceptions of teacher educators and student teachers regarding the undertaking of thesis projects as a formality. This narrow conceptualisation is primarily due to inconsistent understandings and approaches, as well as a lack of commitment between programmes' goals and values and teacher educators' practice, resulting in a fragmented context of teacher-researcher development. Hence, the present study aims to highlight the importance of examining contextual variables, i.e., how teacher-researcher development is understood and approached, in order to ensure sustainable and context-based teacher-researcher development.

In conclusion, teacher-researcher development should be understood as a holistic and complex process within ITE. There is a need to reconceptualise teacher-researcher development beyond technical research skills and research methods courses. Programmes and teacher educators should share a common understanding and commit to multifaceted and continuous teacher-researcher development. Teacher-researcher development must be approached in terms of the work realities of the future teacher and school context improvements, in order to ease student teachers into research activities and influence a change in mindset for dynamic future teacher-researcher engagement (see also: Niemi \& Nevgi, 2014). Research-based teacher education should therefore be a guiding framework for teacher-researcher development in order to improve the quality of initial teacher education.

\section{Limitations and future research}

It should be noted that the examination of teacher-researcher development is limited to programme analysis, teacher educator interviews and an open questionnaire in the Kosovo context. Future studies should consider the student teacher learning process and outcomes when engaging in teacher-researcher development activities. This could provide greater insights into assessing teacher-researcher development. 


\section{References}

Afdal, H. W., \& Spernes, K. (2018). Designing and redesigning research-based teacher education. Teaching and Teacher Education, 74, 215-228. https://www.sciencedirect.com/science/article/abs/pii/ So742051X17314476?via\%3Dihub Alvunger, D., \& Wahlström, N. (2017). Research-based teacher education? Exploring the meaning potentials of Swedish teacher education. Teachers and Teaching, 24(4), 332-349.

Braun, V., \& Clarke, V. (2006). Using thematic analysis in psychology. Qualitative Research in Psychology, 3(2), 77-101.

Buchberger, F., Campos, B. P., Kallos, D., \& Stephenson, J. (2000). Green paper on teacher education in Europe: high quality teacher education for high quality education and training. Thematic Network on Teacher Education in Europe. Umea University.

Creswell, J. W. (2014). Research design: Qualitative, quantitative, and mixed methods approaches.

SAGE Publications.

Darling-Hammond, L. (2016). Research on teaching and teacher education and its influences on policy and practice. Educational Researcher, 45(2), 83-91.

Darling-Hammond, L. (2017). Teacher education around the world: What can we learn from international practice? European Journal of Teacher Education, 40(3), 291-309.

Darling-Hammond, L., \& Bransford, J. (2005). Preparing teachers for a changing world: What teachers should learn and be able to do. Jossey-Bass.

Griffiths, R. (2004). Knowledge production and the research-teaching nexus: The case of the built environment disciplines. Studies in Higher Education, 29(6), 709-726.

Hargreaves, A. (2003). Teaching in the knowledge society. Education in the age of insecurity. Open University Press.

Healey, M. (2005). Linking research and teaching exploring disciplinary spaces and the role of inquiry-based learning. In R. Barnett (Ed.), Reshaping the university: New relationships between research, scholarship and teaching (pp. 67-78). Open University Press/McGraw-Hill Education. Healey, M., \& Jenkins, A. (2009). Developing undergraduate research and inquiry. Higher Education Academy.

Jyrhämä, R., Kynaslahti, H., Krokfors, L., Byman, R., Maaranen, K., Toom, A., \& Kansanen, P. (2008). The appreciation and realization of research-based teacher education: Finnish students' experiences of teacher education. European Journal of Teacher Education, 31(1), 1-16.

Kaçaniku, F. (2017). The impact of the Bologna Process in Kosovo: Prospects and challenges. Journal of the European Higher Education Area, 8(4), 57-76.

Kaçaniku, F. (2020). Towards quality assurance and enhancement: The influence of the Bologna Process in Kosovo's higher education. Quality in Higher Education, 26(1), 32-47.

Kaçaniku, F., Gjelaj, M., \& Saqipi, B. (2019). Context guided instruction to develop reflection competence of education professionals. Review of Education, Pedagogy, and Cultural Studies, 41(1), 48-67. 
Krokfors, L., Kynäslahti, H., Stenberg, K., Toom, A., Maaranen, K., Jyrhämä, R., Byman, R., \& Kansanen, P. (2011). Investigating Finnish teacher educators' views on research based teacher education. Teaching Education, 22(1), 1-13.

Lincoln, Y. S., \& Guba, E. G. (1985). Naturalistic inquiry. Sage.

Munthe, E., \& Rogne, M. (2015). Research based teacher education. Teaching and Teacher Education, 46, 17-24. https://www.sciencedirect.com/science/article/abs/pii/So742051X14001322

Niemi, H. (2008). Advancing research into and during teacher education. In B. Hudson \& P. Zgaga

(Eds.), Teacher education policy in Europe: A voice of higher education institutions (pp. 183-208).

University of Umeå.

Niemi, H., \& Nevgi, A. (2014). Research studies and active learning promoting professional competences in Finnish teacher education. Teaching and Teacher Education, 43, 131-142. https://www. sciencedirect.com/science/article/abs/pii/So742051X14000821

Nowell, L. S., Norris, J. M., White, D. E., \& Moules, N. J. (2017). Thematic analysis: Striving to meet the trustworthiness criteria. International Journal of Qualitative Methods, 16, 1-13. https://journals. sagepub.com/doi/full/10.1177/1609406917733847

Puustinen, M., Säntti, J., Koski, A., \& Tammi, T. (2018). Teaching: A practical or research-based profession? Teacher candidates' approaches to research-based teacher education. Teaching and Teacher Education, 74, 170-179. https://www.sciencedirect.com/science/article/abs/pii/ So742051X17310661?via\%3Dihub

Saqipi, B. (2019). Teacher education policy discourse in the midst of system reorganisation and policy transfer: Lessons for small and developing countries. International Journal of Management in Education, 13(1), 28-39.

Saqipi, B. (2020). Using activity systems theory to understand change process in developing teacher as researcher at master level studies. International Journal of Learning and Change, 12(1), 1-14. Saqipi, B., \& Vogrinc, J. (2016). Developing research competence at pre-service teacher education. Didactica Slovenica, 31(2), 101-117.

Stenhouse, L. (1981). What counts as research? British Journal of Educational Studies, 29(2), 103-114. Toom, A., Kynäslahti, H., Krokfors, L., Jyrhämä, R., Byman, R., Stenberg, K., Maaranen, K., Kansanen, P. (2010). Experiences of a research-based approach to teacher education: Suggestions for future policies. European Journal of Education, 45(2), 331-344.

\section{Biographical note}

FJolla KaÇAniku is currently a PhD researcher at the Faculty of Education, University of Ljubljana, Slovenia. She serves as a Teaching Assistant in the Faculty of Education at the University of Prishtina in Kosovo. Her research interest includes the development of quality-driven and research-based initial teacher education within the broad European context of teacher development. 